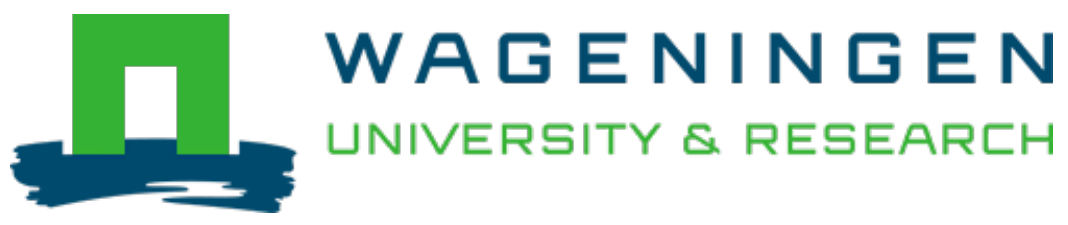

\title{
Microbiological aspects of wheat sour-dough
}

Antonie van Leeuwenhoek: Nederlandsch tijdschrift voor hygiëne, microbiologie en serologie

Creemers-Molenaar, T.; Nout, M.J.R.; Bonants-van Laarhoven, T.M.G.

https://doi.org/10.1007/bf00404593

This publication is made publicly available in the institutional repository of Wageningen University and Research, under the terms of article $25 \mathrm{fa}$ of the Dutch Copyright Act, also known as the Amendment Taverne. This has been done with explicit consent by the author.

Article $25 \mathrm{fa}$ states that the author of a short scientific work funded either wholly or partially by Dutch public funds is entitled to make that work publicly available for no consideration following a reasonable period of time after the work was first published, provided that clear reference is made to the source of the first publication of the work.

This publication is distributed under The Association of Universities in the Netherlands (VSNU) 'Article $25 \mathrm{fa}$ implementation' project. In this project research outputs of researchers employed by Dutch Universities that comply with the legal requirements of Article $25 \mathrm{fa}$ of the Dutch Copyright Act are distributed online and free of cost or other barriers in institutional repositories. Research outputs are distributed six months after their first online publication in the original published version and with proper attribution to the source of the original publication.

You are permitted to download and use the publication for personal purposes. All rights remain with the author(s) and / or copyright owner(s) of this work. Any use of the publication or parts of it other than authorised under article $25 \mathrm{fa}$ of the Dutch Copyright act is prohibited. Wageningen University \& Research and the author(s) of this publication shall not be held responsible or liable for any damages resulting from your (re)use of this publication.

For questions regarding the public availability of this publication please contact openscience.library@wur.nl 


\title{
Microbiological aspects of wheat sour-dough
}

\section{T. Creemers-Molenaar, M. J. R. Nout and T. M. G. Bonants- VAN LAARHOVEN}

\author{
Department of Food Science, Agricultural University, De Dreijen 12, 6703 BC Wageningen, \\ The Netherlands
}

Although sour-dough bread represents only a fraction of the Dutch bread market, there is an increasing interest for this product which has led to the establishment of a growing number of sourdough bakeries. In contrast to Central European sour-dough baking, Dutch sour-dough manufacturers do not use rye-based starters but sour-doughs maintained on wheat flour. The aim of this investigation was to analyse the microflora of commercially used Dutch sour-doughs which have been maintained for several years.

The microbiological components of two representative sour-doughs A and B, and of the flours on which they are maintained, is given in Table 1. Sour-doughs A and B differ considerably in composition: $\mathrm{A}, 100 \mathrm{~g}$ whole wheat flour $+80 \mathrm{ml}$ water; $\mathrm{B}, 100 \mathrm{~g}$ whole wheat flour $+65 \mathrm{ml}$ water $+1.5 \mathrm{~g} \mathrm{NaCl}$. 
Table 1. Microbial counts (in log units) per g of sour-doughs and the corresponding wheat flours

\begin{tabular}{|c|c|c|c|c|}
\hline \multirow[t]{2}{*}{ Microorganisms } & \multicolumn{2}{|l|}{$\mathrm{A}^{1}$} & \multicolumn{2}{|l|}{$\mathrm{B}^{2}$} \\
\hline & Flour & Sour-dough & Flour & Sour-dough \\
\hline Total aerobic & 5.3 & 7.2 & 5.9 & $<4$ \\
\hline Total anaerobic & 5.2 & 7.1 & 5.7 & $<4$ \\
\hline Endospores & 3 & $<1$ & 2 & $<1$ \\
\hline Lactobacillus sp. & $<1$ & 7.7 & $<1$ & 9 \\
\hline Yeasts & 2.6 & 7 & $<2$ & 1.5 \\
\hline Moulds & 2.5 & $<4$ & 2.4 & 2.1 \\
\hline Streptococcus sp. & $<2$ & $<1$ & $<1$ & $<1$ \\
\hline Leuconostoc sp. & $<2$ & 1.3 & $<1$ & $<1$ \\
\hline Staphylococcus epidermidis & 3.6 & $<1$ & 2.9 & $<1$ \\
\hline Micrococcus sp. & 2.9 & $<1$ & $<1$ & $<1$ \\
\hline Enterobacteriaceae & 4.4 & $<1$ & 5.6 & $<1$ \\
\hline Coliforms & $<1$ & $<1$ & $<2$ & $<1$ \\
\hline Escherichia coli & $<1$ & $<1$ & $<2$ & $<1$ \\
\hline
\end{tabular}

${ }^{1}$ Composition $100 \mathrm{~g}$ whole wheat flour $+80 \mathrm{ml}$ water.

${ }^{2}$ Composition $100 \mathrm{~g}$ whole wheat flour $+65 \mathrm{ml}$ water $+1.5 \mathrm{~g} \mathrm{NaCl}$.

Sour-dough A contained high numbers of yeasts and lactobacilli. The majority of isolated yeasts were identified as Saccharomyces exiguus, whereas two species of Lactobacillus were found, viz. L. sanfrancisco and L. brevis var. lindnerii II ( $35 \%$ and $65 \%$ of all isolates, respectively). Sour-dough B contained very high numbers of lactobacilli, all identified as $L$. brevis var. lindnerii II, but only low numbers of yeasts, identified as Sacch. exiguus and Sacch. cerevisiae $(83 \%$ and $17 \%$ of all isolates, respectively). The above organisms are characterized by a restricted assimilation of carbohydrates (API $50 \mathrm{CHL}$ system): $L$. sanfrancisco only assimilates maltose, whereas $L$. brevis var. lindnerii II assimilates maltose and glucose only. The major yeast, Sacch. exiguus, can not assimilate maltose, but only glucose, sucrose, raffinose and trehalose, and resists $10 \mu \mathrm{g} \cdot \mathrm{ml}^{-1}$ actidione. The isolated Sacch. cerevisiae strain had a very weak maltose assimilation and did not resist $10 \mu \mathrm{g} \cdot \mathrm{ml}^{-1}$ actidione.

Our findings are similar to those of Sugihara et al. (1970) and Kline and Sugihara (1970) who found only Torulopsis holmii (imperfect stage of Sacch. exiguus) and L. sanfrancisco in San Francisco sour-doughs maintained for several decades. However, Spicher and Schröder (1978) reported a large variety of yeasts and homo- and heterofermentative lactobacilli to be found in relatively young rye sour-doughs.

Kuine, L. and Sugihara, T. F. 1970. Microorganisms of the San Francisco sour dough bread process II. Isolation and characterization of undescribed bacterial species responsible for the souring activity. - Appl. Microbiol. 21: 459-465.

SPICHER, G. and SCHRÖDER, R. 1978. Die Mikroflora des Sauerteiges IV. Mitteilung: Untersuchungen über die Art der in 'Reinzuchtsauern' anzutreffenden stäbchenförmigen Milchsäurebakterien (Genus Lactobacillus Beijerinck). - Z. Lebensm. Unters. Forsch. 167: 342-354.

Sugihara, T. F., Kline L. and Miller, M. W. 1970. Microorganisms of the San Francisco sour dough bread process I. Yeasts responsible for the leavening action. - Appl. Microbiol. 21: 456-458. 